\title{
Social Capital Formation among Turkish Women
}

\author{
Gizem Arat \\ Ankara Provincial Directorate of Family and Social Policies
}

\author{
Arzu Icağasıoğlu-Çoban \\ Başkent University
}

Gonca Polat

Başkent University

\begin{abstract}
The purpose of the current study was to identify Turkish women's social capital formation. This study consisted of 170 women with low SES residing closer to shantytowns. The authors performed the Logistic regression analysis to examine the social capital formation (civic engagement, trust, social participation, and social networks) of women in terms of six variables (age, educational level, employment and marital status, homeownership, community centers, and the length of stay in the same neighborhood) in four different community centers in Ankara, Turkey. Logistic regression results suggest that the length of stay in the same neighborhood was associated both with staying in touch with neighbors (social networks) and trust in municipal service provision (trust), and women's educational level was associated with voting (civic engagement) and the utilization of municipal services (social participation). Further research should be conducted by comparing men's and women's social capital creation by adding other variables.
\end{abstract}

\section{Introduction}

Social capital can be seen as integrating social networks, trust, and social participation that lead individuals to take actions collectively, such as joining local groups, or voting to solve problems (Lowndes 2004). Putnam defines social capital as "the features of social organization such as networks, norms and social trust that facilitate co-ordination and cooperation for mutual benefit” (Putnam 1995, p.67). With regards to developing and using social capital, there are some differences among women and men (Coulthard, Walker, \& Morgan 2002; Hall 1999; Lowndes 2004; Putnam 1995). With respect to trust and reciprocity, first, women are slightly more likely than men to know and trust their neighbors. Second, 
women are more likely than men to stay in touch with their relatives and friends with regards to social networks (Coulthard, Walker, \& Morgan 2002).

There are six variables that affect women's social capital creation according to Rupasingha, Goetz, and Freshwater (2006). These are:

\section{a. Education}

There is a strong relationship between education and social capital performance in the literature (Putnam 1995; Helliwell \& Putnam 1999; Glaeser, Laibson \& Sacerdote 2002). According to Putnam (1995), education is significantly correlated with social trust and civil engagement. Rupasingha, Goetz, and Freshwater (2006) stated that higher educational status of individuals can result in civic engagement in communities.

\section{b. Employment status}

Holding a job can lead individuals to socialize more, depending on the job type (Glaeser, Laibson \& Sacerdote 2002). For example, a woman working outside the home can go to the movies with friends from her work place which may depict that her social circle consists of friends from her work place rather than neighbors or relatives.

\section{c. Homeownership}

There is a strong relationship between social capital and homeownership (Glaeser, Laibson \& Sacerdote 2002). DiPasquale \& Glaeser (1999) stated that since homeowners do not usually intend to move out, they will try to improve their neighborhood by joining in local activities.

\section{d. Age}

Older people are more likely to engage in civil activities (Putnam 1995), such as joining non-profit organizations. For example, older people who are grandparents are more likely to support the development of young people and may also donate money to improve the circumstances of children and young people.

\section{e. Changing role of women}

Women are increasingly in the paid workforce; therefore, they are less likely to seek to create social capital (Alesina \& La Ferrara 2000). Women, who are housewives and mothers, tend to actively participate in social activities in their local area (Putnam 1995).

\section{f. Marriage and family}

There are some differences in participation levels between married and single people (Putnam 1995). 'Single people are significantly less trusting and less engaged in civic activities than married people’ (Rupasingha, Goetz, \& Freshwater 2006, p.92). 


\section{Community Centers in Turkey}

The predominant role of community centers in Turkey is to strengthen the quality of life of families in collaboration with voluntary and non-governmental organizations, and social services (Çengelci 1993). Community centers help people, groups, and societies enhance problem solving capacities (Koçyıldırım 2001) and 'resolve common problems' (Lowndes 2004, p.47). There are 84 community centers in Turkey. Most community centers are located in shantytowns, while the rest are located in developing regions (Toplum merkezleri listesi 2013).

The target group of community centers to meet the objective of enhancing the well-being of economic deprived families, societies, and communities generally consists of women (Dalyanoğlu 2007) since they are predominantly responsible for the raising of children and managing household tasks. This role has been attributed to women due to the patriarchal nature of society where women are mainly subordinate to men (Mahmud 2003; Scott-Samuel 2009). In such societies, men work outside, while women work in the home; therefore, women's social networks are limited to family and neighbors. As a result, it is easier to reach women first to provide services on health, nutrition, child development, and family planning. In addition to these services, community centers aim at teaching women and children their rights and how to benefit from these (Dalyanoğlu 2007). Through the help and support of community centers, women are more likely to go out and engage with other people.

Additonally, women start to notice the resources around them in terms of opportunities for developing social capital, such as knitting clothes and selling them in kermises (a fundraising fair). Consequently, women become more financially independent and socialize with other people apart from their neighbors and relatives.

\section{The aim of this study}

Unfortunately there is still a paucity of gender studies on social capital in literature (Fox \& Gershman 2000; Kilby 2002; Molinas 1998; Molyneux 2002; Norton 2001). Moreover, among quantitative studies, there is a lack of studies on informal social capital (Pichler \& Wallace 2004). Studies aimed at exploring women's oppression in terms of social capital (e.g. studies of entrepreneurship and trust) have been seen as tackling an important issue recently in Turkey (Çakır 2008, Özen-Kutanış \& Bayraktaroğlu 2003; Özen-Kutanış \& Hancı 2004; Navir 2008; Özdemir 2010, Yağc1 \& Bener 2005; Yetim 2002). Studies focusing on Turkish women's political participation are extremely rare (Kasapoğlu \& Özerkmen 2011). However, 
the studies which do exist have not focused on the measurement of social capital creation among Turkish women in community centers. Thus, the aim of this study was to examine the measurement of women's social capital formation among women involved in community centers. This study, focusing on four different community centers in Turkey, explores the dimensions of social participation, social networks, civic engagement, and trust in relation to age, educational level, employment status, marital status, and homeownership (Rupasingha, Goetz, \& Freshwater, 2006), and the length of stay in a neighborhood.

\section{Methodology}

Participants

The sample consisted of 170 women attending four community centers (Mamak, Altindag, Golbasi, and Natoyolu) in the capital of Turkey, Ankara. Such centers provide social services to economically deprived women and families. These community centers and participants' apartments were located close to shantytowns.

The present study took place from September 2009 to May 2010. It was approved by the Institutional Review Board (IRB) of Social Sciences at Başkent University. Before the data collection instruments were administered, a brief explanation of the aim of the study and the measuring instruments were provided to each director of community centers and written permission was sought to conduct the study within the center. Subsequently, informed consent was obtained from each participant.

\section{Measures}

Questions in the data collection instrument were drawn from the Social Capital Question Bank which is based on the ONS survey matrix (November 2001). This showed what type of information on social capital was being collected in various surveys, such as British Crime Survey (2001), Health Survey of England (2000), Home Office Citizenship Survey (2001), and British Household Panel Survey (2000). The questions were gathered in the survey matrix formed by Blaxter, Poland, and Curran (2001). The question bank was translated into Turkish by the authors.

The first section of the questionnaire was related to demographic characteristics of the participants (e.g., age, gender, educational status, marital status, employment status etc.). The next section was related to social participation regarding the utilization of municipal services 
(e.g., have you received any municipal services because of problems regarding your neighborhood etc.) while the third section was related to social support and social relationships regarding neighbors (e.g., how often do you stay in touch with the neighbors, in an emergency, will you call your neighbor/s to help you etc.). The fourth section was related to civic engagement regarding voting (e.g., have you voted in the last election etc.). The final section was related to trust in municipal service provision (e.g., to what extent do you trust the municipal service provision).

\section{Data analysis}

A rich descriptive picture arose from a descriptive analysis of the original ordinal data and a summary of the demographic data is presented.

The SPSS software 17.0 was used for the statistical analysis, using Logistic regression analysis. A p value of lower than .05 was accepted to be a statistically significant indicator. For Logistic regression analysis, the variables were converted into dummy variables. Questions related to demographic characteristics included gender ( $0=$ females vs. $1=$ males); age $(0=15$ through 43 years vs. $1=44$ through 73$)$; employment status $(0=$ unemployed vs. $1=$ employed); educational status ( $0=$ primary school or less vs. $1=$ further education); homeownership ( $0=$ rent vs. $1=$ own); the length of stay in neighborhood ( $0=$ =between 1 and 10 years vs. $1=$ between 11 and 20 years); trust in municipal services ( $0=$ very little vs. $1=$ =very much); voting ( $0=$ no vs. $1=$ yes).

\section{Results}

Demographic characteristics of women

In this study, women from four different community centers participated. Of the participants, 26.0\% $(n=44)$ attended in Mamak, 25.0\% $(n=43)$ attended in Altindag, $21.0 \%(n=35)$ attended in Golbasi, and 28.0\% $(n=48)$ attended in Natoyolu Community Center. All of these community centers were located in less developed regions where people with low SES reside.

Most of the women were married (89.0\%) while 5.0\% of women were single, $6.0 \%$ of women were widows. Ninety- two percent (92.0\%) of women had children whereas only $8.0 \%$ of women do not have any children. The mean age of women was $26(\mathrm{SD}=1.5)$ and the mean duration of marriage is 12 years ( $\mathrm{SD}=3.77)$. The minimum number of children was 1 and the maximum number of children was 8 . The mean number of children was 2 . 
When the educational level of women was investigated, $8.0 \%$ of the respondents were found to be illiterate, $5.0 \%$ of women could read and write, $42.0 \%$ of women were elementary school graduates, $14.0 \%$ of women were middle school graduates, $26.0 \%$ of women were high school graduates, and $6.0 \%$ of women were college graduates. In terms of participation in the workforce, only 5.0\% of women worked outside home, while $95.0 \%$ of women were only housewives.

\section{Social capital creation among women}

Binary logistic regression using the Enter method helped to identify which of the selected correlates was most important in the prediction of women's social capital creation. The logistic regression model included a total of 7 predictors (age, community centers, educational level, marital status, employment status, the length of stay in neighborhood, and homeownership) related to women's social capital formation (the utilization of municipal services, neighbors, voting, and trust in municipal services). Furthermore, The $\operatorname{Exp}(\mathrm{B})$ statistic, or odds ratio, was analyzed in the present study. It depicts the increase or decrease in odds of being classified in an outcome category when the predictor variable increases by a unit (Tabachnick \& Fidell 1996).

Table 1 Regression coefficients for the utilization of municipal services

\begin{tabular}{lllllll}
\hline Predictor & $\mathrm{B}$ & SE & Wald & Df & P & Exp(B) \\
\hline Age & .070 & .574 & .474 & 1 & .062 & .517 \\
Educational level & .048 & .465 & $.508=]$ & 1 & $.024^{*}$ & 1.435 \\
Marital status & .041 & .887 & .008 & 1 & .063 & .041 \\
Employment status & .682 & .822 & .687 & 1 & .407 & 322 \\
The length of stay & .245 & .448 & .072 & 1 & .150 & .907 \\
in the same & & & & & & \\
neighborhood & & & & & & \\
Homeownership & .116 & .440 & .041 & 1 & .126 & 1.129 \\
Constant & -.893 & .707 & .617 & 1 & .053 & .059 \\
\hline
\end{tabular}
${ }^{*} \mathrm{p}<.05$

The Wald statistics and accompanying significance levels reveal that women's educational level was significant in predicting the utilization of municipal services at the $\mathrm{p}<0.05$ level, controlling for the influences of the other predictors in the model (Wald=.508, $\mathrm{p}=0.024$ ). The odds ratio was 1.435 , showing that for those with a high educational level, they were almost 
43 percent times more likely to utilize municipal services to solve their problems $(\operatorname{Exp}(B)=$ 1.435). Other variables were not statistically significant predictors of women's utilization of municipal services to solve their problems.

Table 2 Regression coefficients for neighbors

\begin{tabular}{lllllll}
\hline Predictor & $\mathrm{B}$ & $\mathrm{SE}$ & Wald & $\mathrm{df}$ & $\mathrm{p}$ & $\mathrm{Exp}(\mathrm{B})$ \\
\hline Age & .668 & .541 & .320 & 1 & .398 & .581 \\
Educational level & -.388 & .537 & .522 & 1 & .470 & .678 \\
$\begin{array}{l}\text { Marital status } \\
\text { Employment }\end{array}$ & -.241 & .151 & .046 & 1 & .471 & .468 \\
$\quad \begin{array}{l}\quad .871 \\
\text { status }\end{array}$ & .214 & .571 & 1 & .224 & .516 \\
$\begin{array}{l}\text { The length of stay } \\
\text { in the same }\end{array}$ & .662 & .544 & .481 & 1 & $.045^{*}$ & 1.783 \\
$\begin{array}{l}\text { neighborhood } \\
\text { Homeownership }\end{array}$ & .622 & .555 & .254 & 1 & .263 & .516 \\
Constant & 2.228 & .230 & 3.279 & 1 & .070 & 6.280 \\
\hline
\end{tabular}

In this study, the length of stay in the same neighborhood significantly predicted their social supports as neighbors (Wald=8.443, $\mathrm{p}=.004$ ). As the length of stay in the same neighborhood increases, women were almost 78 times more likely to stay in touch with their neighbors $(\operatorname{Exp}(B)=1.783)$. Other variables were not statistically significant predictors of women's relationship with their neighbors.

Table 3 Regression coefficients for voting

\begin{tabular}{lllllll}
\hline Predictor & $\mathrm{B}$ & $\mathrm{SE}$ & Wald & df & $\mathrm{P}$ & Exp(B) \\
\hline Age & .114 & .085 & 1.055 & 1 & .304 & .304 \\
Educational level & .303 & .508 & .356 & 1 & $.045^{*}$ & 1.503 \\
Marital status & .305 & .812 & .586 & 1 & .108 & .668 \\
Employment status & -.209 & 11.26 & .034 & 1 & .853 & .812 \\
The length of stay & -.029 & .520 & .003 & 1 & .895 & .971 \\
in the same & & & & & & \\
neighborhood & & & & & & \\
Homeownership & .401 & .503 & .635 & 1 & .425 & .493 \\
Constant & .543 & .908 & .358 & 1 & .550 & .721 \\
\hline
\end{tabular}

In the current study, women's educational level predicted women's political participation defined as voting (Wald=.356, $\mathrm{p}=.0045$ ). Women with a high educational level were almost 
50 times more likely to vote $(\operatorname{Exp}(B)=1.503)$. Other variables were not statistically significant predictors of women’s political participation.

Table 4 Regression coefficients for trust in municipal service provision

\begin{tabular}{lllllll}
\hline Predictor & B & SE & Wald & Df & P & Exp(B) \\
\hline Age & .763 & .531 & .063 & 1 & .151 & .144 \\
Educational level & .185 & .343 & .290 & 1 & .090 & .203 \\
Marital status & .637 & .774 & .245 & 1 & .411 & .890 \\
Employment status & -.456 & .578 & .019 & 1 & .313 & .451 \\
The length of stay & .93 & .357 & .210 & 1 & $.026^{*}$ & 1.277 \\
in the same & & & & & & \\
neighborhood & & & & & & \\
Homeownership & .244 & .337 & .526 & 1 & .468 & .314 \\
Constant & .027 & .123 & .508 & 1 & .212 & .358 \\
\hline
\end{tabular}
${ }^{*} \mathrm{p}<0.05$

The variable, the length of stay in the same neighborhood, was the only significant predictor of women's trust in municipal service provision in the logistic regression analysis (Wald $=.210, \mathrm{p}=0.026)$. As the length of stay in the same neighborhood increases, women were 12 percent more likely to trust in municipal service provision $(\operatorname{Exp}(B)=1.277)$.

\section{Discussion}

This study was conducted to measure the variables (age, homeownership, employment status, educational level, marital status, and the length of stay in neighborhood) with respect to social capital creation (social participation, social networks, civic engagement, and trust) among Turkish women ( $\mathrm{n}=170)$ attending four community centers in Ankara, capital of Turkey.

Women's social capital tends to be more tied to informal social circles (Lowndes 2004), such as neighbors. Indeed, neighbors are often part of the extended family in shantytowns in Turkey (Gökçe 1993). Consistent with Gökçe’s study (1993), the length of stay in the same neighborhood predicted women's relationship with their neighbors in the current study. Based on the current study findings, as women's length of stay in the same neighborhood increases, they are more likely to stay in touch with their neighbors. Based on the observations of the authors, participants remained in contact with their neighbors on a regular basis if they lived in the same neighborhood more than 10 years. These neighbors are likely 
to include close family relatives, such as aunts and parents in such areas. In Turkish culture, there is a popular Russian proverb that says “Don’t buy the house, but the neighborhood”. This saying resonates with the findings of this current study.

It is not surprising that women's educational attainment was strongly related to voting (civic engagement) and the utilization of municipal services (social participation) in the present study. Women with further education are more likely to engage in politics than women with primary education or less. Consistent with the findings of this current study, Losindilo, Mussa, and Akarro (2010) stated that Tanzanian women who have a higher level of education are more likely to vote and engage in social participation and Coley and Sum (2012) found that both men and women in America with a higher level of education were more likely to vote and to use municipal services.

The present study confirmed that as women's length of stay in the same neighborhood level increases, women are more likely to trust in municipal service provision. This could be a result of voting. Since women's political participation increases, they may stay in touch with municipal service providers more often to improve their neighborhood's condition. Based on the authors' observations, almost all of the neighborhoods consist of many malls, restaurants, parks, schools, and playgrounds for children within walking distance. Even if these are far away from the places where they live, public transport makes them easily accessible. People who live in the same neighborhood for many years are more likely enjoy the options that municipalities provide (Leyden 2003).

\section{Limitations of the study}

In this study, certain limits should be acknowledged in both interpreting the results and in planning future investigation. First, the sample size is not representative of Turkey as a whole, since the study was conducted only in Ankara, the capital of Turkey. Secondly, the binary logistic regression analysis allowed statistically significant variables to emerge but at the same time, it minimized the opportunity to identify more subtle influences in women's creation of social capital. Finally, more empirical studies using mixed methods are needed to compare social capital creation among men and women. 


\section{Conclusion}

This study is significant because it is one of the few which explores women's formation of social capital. It attempts to go beyond a descriptive analysis to identify the relationship of age, education, employment, and marital status, and homeownership, and the length of stay in neighborhood to social capital formation by women in four different community centers in Turkey. The findings highlight that women's educational attainment and the length of stay in the same neighborhood affect their social capital creation as measured by trust in municipal service provision, the utilization of municipal services, social network, and social participation.

\section{References}

Alesina, A. \& La Ferrara, E. 2000, 'Participation in heterogeneous communities', Quarterly Journal of Economics vol. 115, pp. 847-904.

Blaxter, M., Poland, F., \& Curran, M. 2001, Measuring social capital: Qualitative study of how older people relate social capital to health, Final report to the Health Development Agency, London.

Çakır, O. 2008, Türkiye'de kadının calışma yaşamından dışlanması [The exclusion of women from working outside home in Turkey]. Erciyes Üniversitesi Iktisadi ve Idari Bilimler Fakültesi Dergisi, vol. 31, pp. 25-47.

Coley, R. J. \& Sum, A. 2012, Fault lines in our democracy: Civic knowledge, voting behavior, and civic engagement in the United States. Retrieved from http://www.ets.org/s/research/19386/rsc/pdf/18719_fault_lines_report.pdf

Coulthard, M., Walker, A. \& Morgan, A. 2002, People's perceptions of their neighborhood and community involvement. The Stationery Office, London.

Çengelci, E. 1993, Sosyal refahın gerçekleştirilmesinde sosyal yardımların rol ve önemi [The importance of social help while fulfilling social welfare]. Hacettepe Universitesi Sosyal Hizmetler Yuksekokulu Dergisi, 11.

Dalyanoğlu, D. 2007, Toplum merkezi hizmetlerinin kadının kente uyum sürecine etkisi.[The influence of community center services on women's in adaptation process to urban life], Master's thesis, Hacettepe University, Institute of Social Sciences, Department of Social Work, Ankara, Turkey.

DiPasquale, D., \& Glaeser, E. L. 1999, 'Incentives and social capital: Are homeowners better citizens?’ Journal of Urban Economics vol. 45, pp. 354-384.

Fox, J., \& Gershman, J. 2000, 'The World Bank and social capital: Lessons from ten rural development projects in the Philippines and Mexico’, Policy Sciences vol. 33, pp. 399419.

Glaeser, E. L., Laibson, D. \& Sacerdote, B. 2002, 'The economic approach to social capital', Economic Journal, vol. 112, 437-458.

Gökçe, B. 1993, Gecekondularda aileler arası geleneksel dayanışmanın çağdaş organizasyonlara dönüşümü [The transition of traditional solidarity of the families in 
shantytowns into modern organizations]. Ankara: Başbakanlık Kadın ve Sosyal Hizmetler Müsteşarlı̆̆ı Yayınları.

Hall, P. 1999, 'Social capital in Britain’, British Journal of Political Science, vol. 29, no.3, pp. 417-461.

Helliwell, J. \& Putnam, R.D. 1999, Education and social capital. NBER working paper series \#7121, National Bureau of Economic Research, Cambridge: MA.

Kasapoğlu, A. \& Özerkmen, N. 2011, ‘Gender imbalance: The case of women’s political participation in Turkey’, Journal of International Women’s Studies, vol. 12, no.4, pp. 97-107.

Kilby, P. 2002, Social capital and civil society. Canberra: National Centre for Development Studies, Australian National University.

Koçyıldırım, Ş. 2001, Kentleşme sürecinde halk katılımı ve sosyal hizmet: Toplumsal gelişme ve değişme sürecinde sosyal hizmet [The community participation and social work in the urbanization process: Social work along with the community development]. Ankara: Hacettepe Üniversitesi Sosyal Hizmet Yüksekokulu.

Leyden, K. M. 2003, 'Social capital and the built environment: The importance of walkable neighborhood', Research and Practice, vol. 93, no. 9, pp. 1546-1551.

Losindilo, E., Mussa, A. S. \& Akarro, R. R. J. 2010, 'Some factors that hinder women participation in social, political, and economic activities in Tanzania’ Art and Social Sciences Journal, vol. 4, pp. 1-10.

Lowndes, V. 2004, 'Getting on or getting by? Women, social capital and political participation', The British Journal of Politics and International Relations, vol. 6, pp. 47-66.

Mahmud, S. 2003, 'Actually how empowering is microcredit?' Development and Change, vol. 34, no. 4, pp. 577-605.

Molinas, J. R. 1998, 'The impact of inequality, gender, external assistance and social capital on local-level cooperation', World Development, vol.26, pp. 413-431.

Molyneaux, M. 2002, 'Gender and the silences of social capital', Development and Change, vol.33, no.2, pp.167-188.

Navir, Z. D. 2008, Iş ve ailesi arasındaki kadın: Tekstil ve bilgi işlem girişimcilerini rol çatışmasına getirdikleri çözüm stratejileri [Women between work and family: The strategical approaches to solve role conflict among entrepreneurs]. Ege Akademik Bakış Dergisi, vol. 8, no. 2, pp. 631-650.

Norton, A. 2001, 'The market for social capital', Policy, 40-44.

Özdemir, A. A. 2010, Potansiyel girişimci olan kadinlarin motivayon faktörleri ve Eskişehir'de bir araştırma [The motivation factors of potential entrepreneurs and a research study in Eskisehir]. Ege Akademik Bakış, vol. 10, no.1, pp. 117-139.

Özen-Kutanış, R. \& Bayraktaroğlu, S. 2002, Female entrepreneurs: social feminist insights for overcoming the barrier. Retrieved from http://www.mngt.waikato.ac.nz/ejrot/cmsconference/2003/proceedings/gender/Ozen$\underline{\text { Kutanis.pdf }}$

Özen-Kutanış, R. \& Hanc1, A. 2003, Women entrepreneurs' perceptions of personal freedom. Retrieved from http://iibf.ogu.edu.tr/kongre/bildiriler/11-02.pdf. 
Pichler, F. \& Wallace, C. 2007, 'Patterns of formal and informal social capital in Europe', European Sociological Review, vol. 23, no. 4, pp. 423-435.

Putnam, R. 1995, 'Tuning in, tuning out: The strange disappearance of social capital in America’, PS:Political Science and Politics, vol. 28, no.4, pp. 665-683.

Rupasingha, A., Goetz, S. J. \& Freshwater, D. 2006, 'The production of social capital in US counties', The Journal of Socio-Economics, vol. 35, pp. 83-101.

Scott-Samuel, A. 2009, 'Patriarchy, masculinities and health inequalities', Gaceta Sanitaria, vol. 23, no.2, pp. 159-160.

Toplum merkezleri listesi (2013) [The list of community centers]. Retrieved from http://www.coksesli.net/altin-rehber/10412-shcek-toplum-merkezleri.html

Yağc1, F.\& Bener, Ö. 2005, Girişimci kadınların demografik ve genel karakteristikleri ile kadınları girişimciliğe motive eden faktörler [The motivation factors that help women integrate in entrepreneurship]. Türk Dünyası Sosyal Bilimler Dergisi, vol. 33, pp. 85100.

Yetim, N. 2006, Sosyal sermaye olarak kadın girişimciler: Mersin örneği [Women entrepreneurs as social capital: Mersin sample]. Retrieved from http://eab.ege.edu.tr/pdf/2_2/C2-S2-\%20M8.pdf 